\title{
The use of swaps by local administrations: the case of Italian regions, 2007-2014
}

\author{
Giulia Fantini (Corresponding Author)
}

Swansea University - School of Management, Room 230, Fabian Way, Bay Campus, Swansea, Wales SA1 8EN, United Kingdom

Email g.fantini@swansea.ac.uk

Orcid: 0000-0001-6923-0929

\section{Chiara Oldani}

University of Viterbo "La Tuscia" - Department of Economics and Engineering, via del Paradiso, 01100 Viterbo, Italy

Email coldani@unitus.it

Orcid: 0000-0002-0203-3864

\section{Acknowledgements}

We would like to thank Pietro Maffettone - University of Naples, the discussant of the 23rd Multinational Finance Conference 2016, Kyriaki Kosmidou - Aristotle University of Thessaloniki, and the discussant of the New Public Sector Seminar, David Heald University of Glasgow for their useful comments and suggestions. All errors are solely the authors' responsibility. 


\section{The use of swaps by local administrations: the case of Italian regions, 2007-2014}

\section{Structured abstract}

Purpose (mandatory) — This study contributes to the literature on local administrations' debt and attempts to answer the following research questions: i) What effects do swaps produce on regions' debt? ii) Have swaps been used to finance discretionary debt?

Design/methodology/approach (mandatory) - The paper investigates the debt burden as influenced by economic, financial and political variables and forces with panel data techniques, and tests whether swaps have been used to financing debt due to unfunded expenditures.

Findings (mandatory) — Panel data results of 15 Italian regions over the 2007-2014 period shows that regions with higher debt exhibited a higher interest rate exposure and have employed derivatives hoping to counterbalance the reduced resources received from the central state, in line with other European countries' experience (i.e., France and Greece).

Research limitations/implications (if applicable) - The scarcity of official data and information on swaps has limited the empirical investigations in the literature but did not reduce the losses of local administrations.

Originality/value (mandatory) - This study creates the first database on swaps purchased by Italian regions to investigate their impact on their debt. Results show that highly indebted regions with reduced funds from the central state and diminished local resources are more likely to use swaps to fund their debt. Italian regions heavily depended on long-term debt to finance their non-healthcare services, rather than current revenues; swaps have been used to finance discretionary (non-healthcare) debt. 


\section{Introduction}

This paper investigates how financial derivatives have been used to finance discretionary debt by Italian Regions after the financial crisis. There has been limited research examining the use of swaps by local governments pre - and post - Great Recession and there is no access to data on Over The Counter (OTC) derivatives used by local administrations because of confidentiality. Therefore, we manually collected data on derivatives' usage from 2007 to 2014 from the annual reports of the Italian Corte dei Conti, the Italian public audit court (2016 and previous years). Before 2007 most Mediterranean countries adopted the cash-based accounting method, which limited the availability of data on OTC derivatives instruments by central and local administrations. After the introduction of accrual accounting by most European countries in 2007, which represented a significant improvement in the transparency and accountability (Brusca and Montesinos, 2010), researchers have been able to collect data on derivative usage by Italian regions.

Monitoring and supervision of swaps is difficult for the Italian public sector. Indeed, swaps are not traded through exchanges or intermediaries, but they are governed by the International Swaps and Derivatives Association (ISDA) Master Agreement. The Bank of Italy publishes yearly data on OTC contracts underwritten by local administrations (only) with Italian banks. The Italian Treasury holds a supervisory role over regions, and since 2009 has monitored the financial effects of swaps. Lastly, the Corte dei Conti (2016 and previous years) monitors their juridical effects, and in its annual reports, it has explicitly condemned the debt management practices of local administrations requesting Parliamentary intervention, rigorous accounting and management rules.

As the result of a large reform effort undertaken in 2001, Italy has moved decidedly toward a federal model of governance. The Italian federal reform helped to improve accounting transparency and reinforced the so-called 'horizontal' accountability, from the administration towards citizens and other stakeholders (Mabillard and Zumofen 2016, p. 6); however, the information on financial risks is still relatively poor, reducing the 'vertical' transparency of debt management in the hierarchy between organizations. Despite the aforementioned efforts Italian regions have been asked to manage an increasing portfolio of duties vis a vis their citizens. The latter, coupled with poor growth and the decrease of state transfers (i.e. fiscal austerity) contributed to a marked increase in their debt, which doubled in the 2007-2014 period.

The previous literature confirmed that the principal-agent theory (Lane, 2005) explained 
the opportunistic use of derivatives by local administrations in need of funding (i.e. the agents), given the opaque information available to the central state (i.e. the principal). The main duty of Italian regions is the supply of healthcare services, whereas the provision of non-healthcare services (e.g. transport, education, training, and infrastructures) is discretionary and its extent varies depending on the specific region. Therefore, debt originating from (unfunded) non-healthcare expenditures is considered discretionary and swaps can be used to fund it.

Our results show that regions with higher debt exhibited a higher interest rate exposure and employed derivatives in their attempts to counterbalance the reduced resources received from the central state. This result is in line with what happens in other European countries like France and Greece.

This research is of interest to academics, practitioners, and policymakers as it investigates the impact of swaps on local debt issued by Italian regions after the Great Recession, it provides evidence of the use of swaps to counterbalance the reduced resources (not only to hedge the interest rate risk), and offers policy implications that could be of help for other countries.

The structure of the paper is as follows: Section II reviews the literature, Section III discusses the research goals and methodology, Section IV describes the empirical data, Section V presents the econometric results, and the last section lays out the study's main conclusions.

\section{Literature review}

This paper contributes to the empirical literature on the use of derivatives by local administration after the financial crisis of 2007.

To date, theoretical and empirical research on derivative usage by the corporate sector (e.g. Bodnar, Consolandi, Gabbi, Jaiswal-Dale, 2013; and Bartram, 2019) is vast. Previous studies showed that large companies were more likely to use financial derivatives. The main drivers can be identified in the economies of scale, in hedging requirements to maximize corporate value, or maximizing risk-averse manager's utility. Several studies investigated the use of derivatives in federal countries, especially those adopting the International Public Sector Accounting Standards (IPSAS) such as Brailsford, Heaney and Oliver, (2005); Stewart and Cox (2008); Howell-Moroney and Hall (2011); Luby (2012); Denison and Gibson (2013); Luby and Singla (2014); and 
Khumawala, Ranasinghe and Yan (2016). A detailed description of purpose, mechanism and risks of swaps in the public sector is that by Luby and Kravchuk, 2013 (pp. 280-288). Brailsford, Heaney and Oliver (2005) found that the determinants of derivatives' use by Australian Commonwealth public sector organizations were size and liabilities. Furthermore, organizations that faced a greater budget complexity or paid tax and dividends were more likely to use derivatives. Stewart and Cox (2008) reported that the notional value of derivatives signed by 100 of the largest U.S. municipalities in 2003 was $\$ 10.6$ billion. Luby (2012) reviewed the use of debt-related derivatives by the city of Chicago and concluded that refinancing problems were mainly related to the pricing and debt management mistakes, and derivative-borne moral hazard. Luby and Kravchuk (2013) reported that the use of derivatives by U.S. states and municipalities increased between 2003 and 2009 because of 'their long-term efficacy but also because of the lack of flexibility in unwinding these financial contracts in a cost-effective manner' (p.306). Luby and Singla (2014) surveyed the use of debt-related derivatives by 30 U.S. states in the period 2005-2010 and discovered that only 20 had public policies guiding their management. Therefore, according to these studies, highly indebted and financially sophisticated states used more derivative contracts. U.S. local administrations did not purchase swaps with large sums of money up-front because these clauses were not very transparent to the public. A few public administrations have filed for bankruptcy due to financial mismanagement involving swap contracts: for example, the $\$ 2$ billion default by Orange County (California) in 1994 and the $\$ 4$ billion default by Jefferson County (Alabama) in 2011 were caused by excessive financial risks (Denison and Gibson, 2013; Howell-Moroney and Hall, 2011). Khumawala, Ranasinghe, and Yan (2016) showed that over half of the U.S. municipal sector between 2005 and 2008 used swap contracts mainly to manage the interest rate risk exposure; they were the largest and financially constrained entities. They found that 'more sophisticated managers of large municipalities and less sophisticated managers of small municipalities are more likely to engage in derivative transactions' (p.303).

Due to the lack of official data, very few research studies have investigated the use of swaps at either the central or local level in Europe. Piga (2001) documented the strategic use of swaps by central European governments to shrink their budget deficit before adopting the euro (i.e. France, Italy and Greece). This window-dressing effect was achieved thanks to inadequate accounting standards at the time. Italy and France used interest rates and currency swaps to reduce interest payments in 1997-1998, as these were 
'two critical years for the European Monetary Union process needed to keep the budget deficit-to-GDP ratio within the 3\% level required by the Stability and Growth Pact' (Piga, 2001, p. 208). Lagna (2016) showed that during the 1993-1999 period, Italian governments implemented 'statecraft strategies by exploiting the market-based methods and technologies of financial innovation' (p. 178) and gained from financial speculation. Local administrations in Europe mimicked the behaviour of the central state; Pérignon and Vallée (2017) empirically verified, using proprietary data from 2,700 French local authorities that complex OTC contracts (i.e. structured loans) sold by Dexia Crediop from 2000 to 2009 were employed to 'obfuscate budget imbalances and [...] help incumbent politicians win a re-election' (p. 1904). The use of structured loans shifted interest payments in the future. As a result, in 2015, 676 local French administrations asked for state rescue because they were unable to repay their loans, especially those indexed to the Swiss Franc exchange rate (which had implicit rates varying from $12.5 \%$ to $81 \%$ ), with losses worth $€ 2$ billion (Cour des Comptes, 2017). Italian and French local administrations extensively used swaps, and similarities between these two countries were relevant (Oldani, 2019). Indeed, local administrations in both countries enjoyed little control and supervision.

During the last decade, reforms have been introduced in the management of public entities and have been based on two paradigms, which are the New Public Management (NPM) and the Principles of Good Governance.

The reform of the accounting systems in Europe aimed at increasing the transparency and timeliness of publicly available information, in particular, with the adoption of the accrual accounting system and the use of the financial statements. A consequence of these changes has been the devolution of the financial delegation and budget accountability to public managers; in turn this has led to public managers' performance being judged according to the same parameters generally used in the corporate sector. A part of the literature argued that accrual accounting can allow managers and politicians to exercise discretion while reporting assets and liabilities and recognizing revenues and expenses, pushing for accounting manipulation and earnings management. Indeed, Cohen, Bisogno and Malkogianni (2019) empirically verified that Italian local governments engaged in earning management in the 2008-2015 period, after the introduction of accrual accounting. The adoption by Italian local administrations of the financial statement had certain positive effects on accountability and performance. However, social legitimization seemed to put pressure on Italian local government officers more than 
accountability patterns or performance analysis (Carini, Giacomini, and Teodori, 2018). Brusca and Montesinos (2010) described the development of accrual accounting among European countries, and Soverchia (2010) compared Italy with the U.S. and the European Union to highlight differences that could substantially reduce financial transparency and increase suspicions of accounting manipulation.

With this paper, we fill an important gap in the literature and describe how swaps have been employed by Italian regions, and which effects they produced on their debt position.

\section{Research design: goals and methodology}

The present study attempts to answer the following research questions: i) What effects do swaps produce on Italian regions' debt? ii) Have swaps been used to finance discretionary spending?

To answer these research questions, this study focuses on ordinary statute regions (ORS), the first level of local administration, representing over $75 \%$ of the Italian territory and population (Piedmont, Lombardy, Veneto, Liguria, Emilia-Romagna, Tuscany, Umbria, Marche, Lazio, Abruzzi, Molise, Campania, Apulia, Basilicata and Calabria). Border regions and the islands, which enjoy a higher level of autonomy - especially in terms of revenues - are thus excluded.

Over the past few years, Italy has consistently ran a primary surplus. However, the debt reduction program has also diminished the amount of resources transferred to local administrations, which introduced local taxes to fund their expenditures. Regions' expenditures have not decreased, due to rising healthcare costs and to an ageing population. In the absence of expenditure cuts, Italian regions have covered their fiscal needs with a mix of new taxes and increased borrowing. In addition, the nature of the aforementioned mix is plausibly influenced by the national and international economic context: negative or stagnating growth between 2007 and 2014 is likely to have tipped the balance towards more debt rather than sharp increase in taxes and services' reduction. We thus expect that regions with high outstanding debt are unlikely to cut services and increase taxes, and are instead very likely to further increase their debt.

Regions' debt can be financed with bonds sold to professional investors, loans with the financial agency of the Italian Treasury, and cash from the Treasury. The Republic of Italy guarantees the liabilities of all regions, but their debt repayment capacity depends on revenues (Piperno, 2013). Since 1998, over 65\% of regional debt has been in the form 
of loans (Banca d'Italia, 2018). Total regional debt was €14 billion in 1998, €27 billion in 2007, and $€ 57$ billion in 2014 (figure 1).

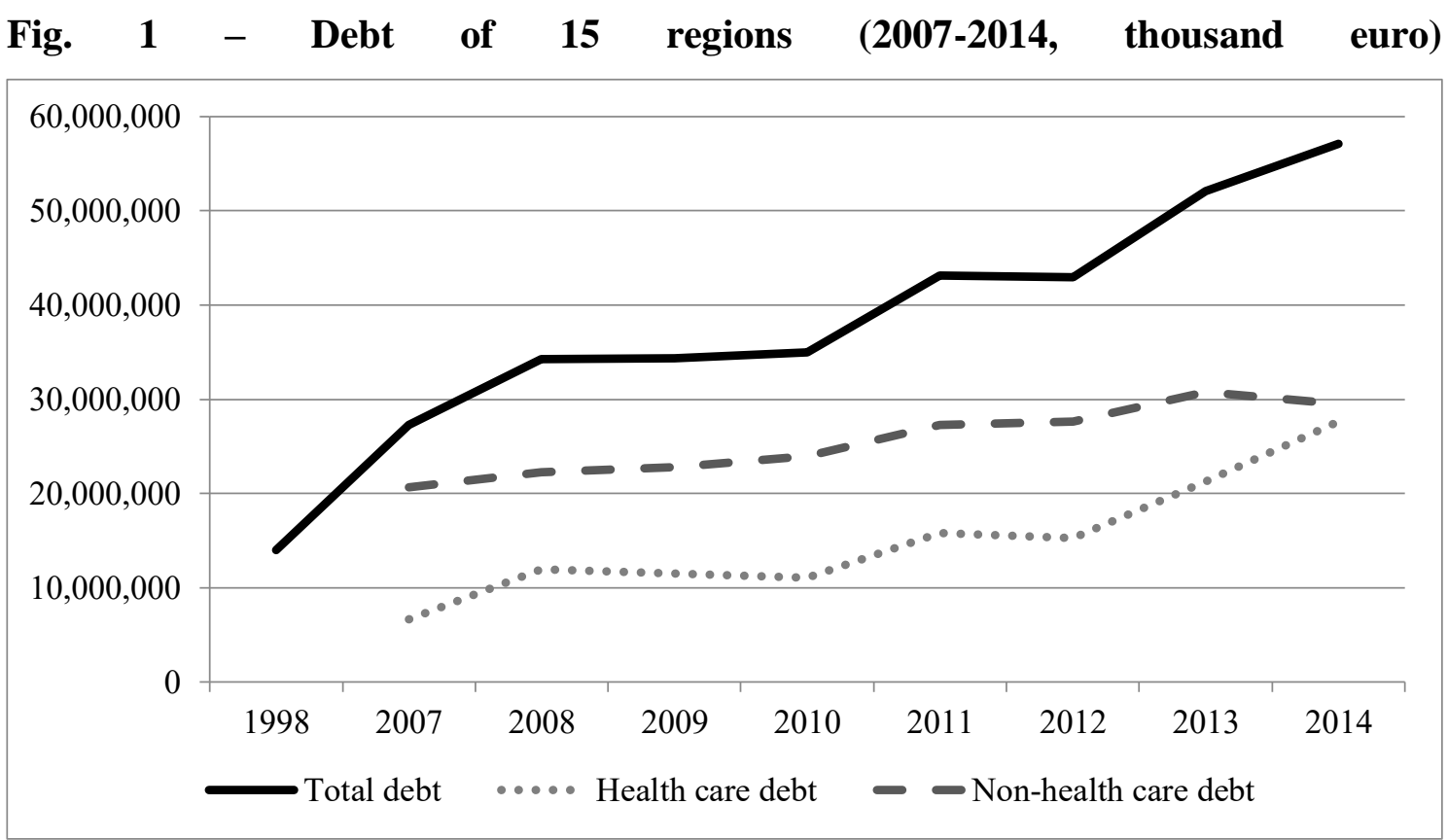

Source: Corte dei Conti, Relazione sulla gestione finanziaria delle Regioni, 2001-2016.

During the period under observation (2007-2014) Italian regions issued fixed-rate debt (with Cassa Depositi e Prestiti) and swapped it with floating rate contracts (often with caps and floors) to lock in their maximum interest expense and gain from decreasing interest rates. Information provided by authorities on swaps, such as the Corte dei Conti (2016 and previous years) excluded the shifting of debt forward and up-front payments. Regions described their liabilities, including swaps in the financial statement in the following way: 'An interest rate swap is an agreement between two parties to exchange a series of interest payments based on a notional amount of debt (usually a specified amount of outstanding bonds) without exchanging the underlying debt. The economic benefit from an interest rate swap is a result of the principle of comparative advantage. This comparative advantage emanates from imperfections in different money and capital markets' (Luby 2012, p.4)

Campania represents a useful example (Campania 2018) and Fig. 2 shows the financial structure of a swap contract. Campania is a large and densely populated region in the South of Italy, and used a swap contract in 2003, expiring in 2023. The underlying asset was a variable rate (indexed at the Euribor) mortgage of $€ 850$ million with Cassa Depositi and Prestiti; counterparts of the interest rate swap were BNL (today part of BNP Paribas 
group), Dexia Crediop, JP Morgan and Banca Intesa. During the 2009-2014 period, the Euribor rate has been lower than 5.5\%, and Campania paid 5.23\% (5.73\% after 2015) fixed interest rate to banks, instead of the (lower) Euribor rate. The region did not reduce its interest's expenses with the swap contract. In 2014, the mark-to-market of this swap was negative for $€ 115$ million, in 2018 was negative $€ 60$ million. In 2018, the synthetic cost of the debt, including the swap, was $3.745 \%$, diminishing in the following 2 years (3.456\% and $3.149 \%$ respectively in 2019 , and 2020 ).

\section{Figure 2. Region swap payoff scheme}

Notional value $€ 850$ million, period 2009-2014

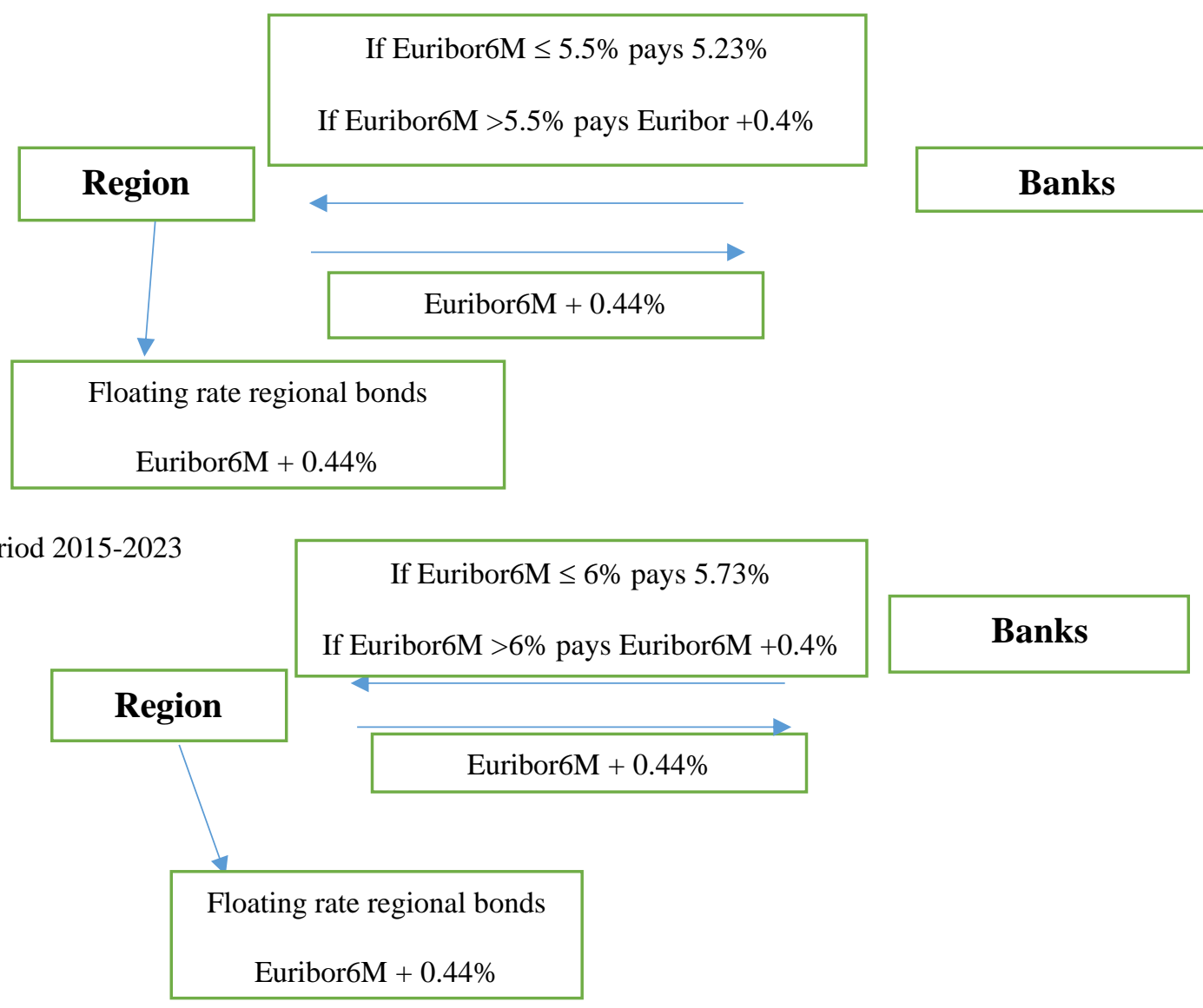

In the 2007-2014 period, the notional value of swaps of the 15 regions reached $€ 12$ billion (figure 3). Data on swaps (notional value, gross market value, fees or other payments, and revenues) have not been disclosed by Italian authorities because of contracts' confidentiality; therefore, we manually collected them from the annual reports of the Corte dei Conti (2016 and previous years). According to the data, their use greatly varied 
amongst Italian regions: in particular, Piedmont, Lazio, and Campania had over $€ 1$ trillion of yearly notional value outstanding, whereas Basilicata had negligible exposure.

As a result of the growth of debt, the ratio between the notional value of swaps and debt decreased over the 2007-2014 period. Regions that exhibited a ratio of swaps on total debt greater than 50\% are Liguria, Abruzzi, Molise, and Campania, but only the debt of Campania follows an explosive path.

Fig. 3 - Swap notional value (thousand euro) of 15 regions and with respect to debt (\%) 2007-2014

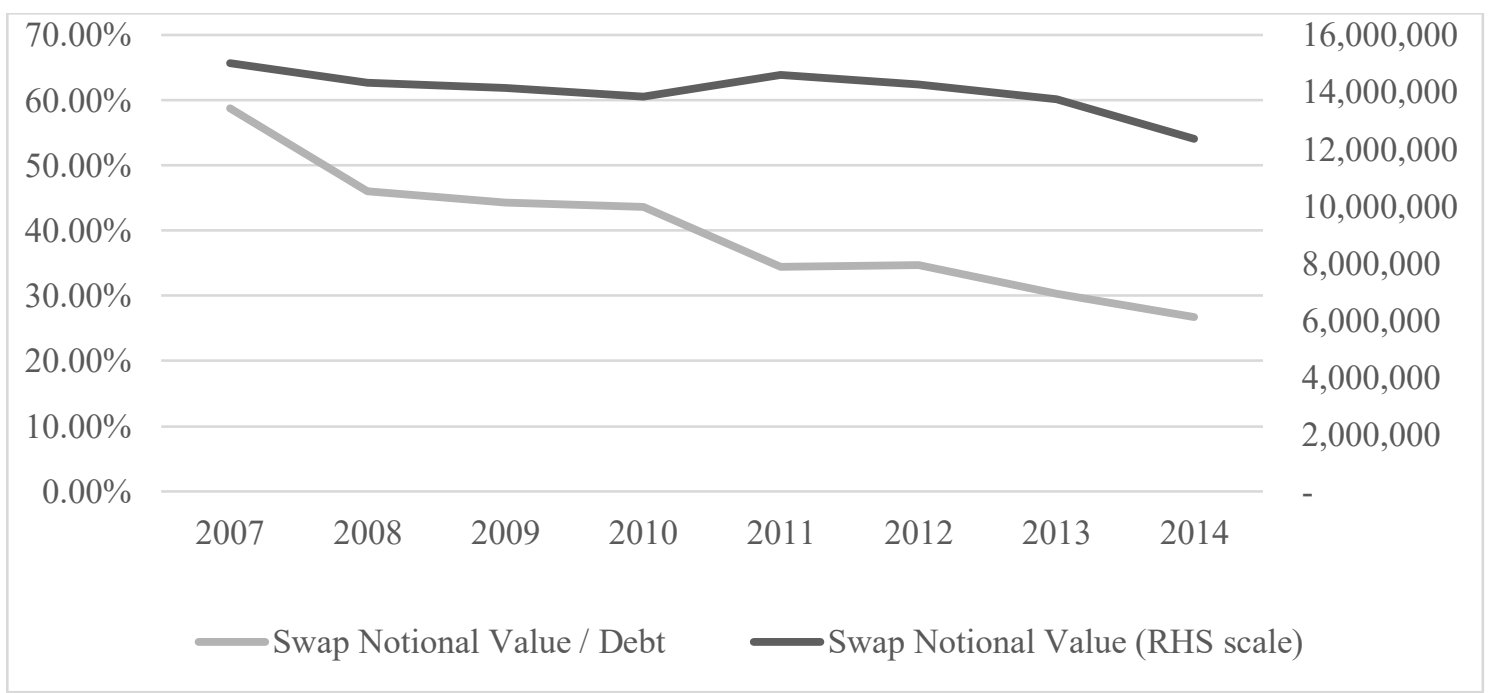

Source: Corte dei Conti, Relazione sulla gestione finanziaria delle Regioni, 2001-2016.

The literature has given scant attention to the debt capacity and affordability of Italian local administrations, and contrary to the U.S. experience, chief financial officers are not provided with any guiding principles for liabilities' management. The debt burden of local administrations has been influenced by economic, political, and demographic variables and forces, as follows (Bahl and Duncombe, 1993; Kriz and Wang, 2012; Rodríguez Bolívar, Navarro Galera, Alcaide Muñoz, and López Subirés, 2016):

Total debtit $=c+\alpha X_{i t}+\gamma_{t}+v_{i}+\varepsilon i t$

where $i$ refers to region and $t$ to year; Total debt refers the total debt of the administration; $X$ is a set of socio-economic variables and financial determinants of the debt of local administration, such as the GDP of the area (i.e. North, Centre, and South), tax revenues, the political party governing the region, and interests paid on debt and other liabilities; $\gamma_{t}$ 
is a year dummy, and $v_{i}$ is a region dummy. This framework is flexible enough to consider financial innovation, such as swaps, among the determinants of debt, and has already been applied to Italian regions by Figari and Gandullia (2008), who investigated the debt dynamics of Italian regions in the 1996-2003 period (before the regions used swaps and before the full implementation of federalism) by considering local variables (i.e. population and local GDP) and financial variables (i.e. taxes and transfers from the central state) as determinants of debt.

To answer the first research question, we empirically investigate the determinants of total debt for Italian regions, as follows:

$$
\begin{aligned}
& \text { Total debtit }=c+\alpha \text { Interest expense } i t+\beta G D P \text { localit }+\gamma \text { Political partyit }+ \\
& +\tau \text { Tax revenue } i t+\delta \text { Notional value } i t
\end{aligned}
$$

where Total debtit represents the debt of $i$-th region in year $t$. The main drivers of a region's total debt in equation (2) are its costs, Interest expenseit and the size of the region, as measured by GDP localit, which is the GDP of the area (i.e. Northeast, Northwest, Centre, and South). We consider also the GDP per capita as a measure of the region's size, but econometric results do not change. The leading Political partyit helps explain the dynamics of debt because, throughout the history of Italy, left-wing parties have contributed to debt stockpiling. Tax revenueit is the most relevant revenue of regions and strongly affects their ability to repay debt, according to standard public finance theory. Equation (2) is estimated with a fixed-effects model because the legislation on regions' liabilities changed over the period under observation, and the Hausman test supports this choice. Following the literature and with the heteroscedasticity found through the Breusch-Pagan test on the ordinary least squares (OLS) results, this study employs the robust OLS estimator.

The effect of swaps on the total debt is measured considering the Notional valueit of contracts: this variable is the nominal exposure at the reporting date (i.e. at the end of the year). We choose to employ the notional value of OTC contracts to be consistent with the methods employed in other countries' case studies (Khumawala, Ranasinghe, and Yan, 2016; Stewart and Cox, 2008).

To answer the second research question, following Pérignon and Vallée (2017), who empirically verified that toxic loans amplified the principal-agent problem in the French political system using a rich dataset, this study tests whether swaps have been used by 
Italian regions to finance discretionary debt (after the federal reform of the State, debt originating from (unfunded) non-healthcare expenditures is considered as discretionary). It is then relevant to estimate whether derivatives' notional market value is driven by nonhealthcare debt and interest expenses:

Notional value $i t=c+\alpha$ Non-healthcare debtit $+\beta$ Interest expense it

where Notional valueit refers to the derivative contracts of the $i$-th region in year $t$, Nonhealthcare debtit is debt unrelated to healthcare services and Interest expenseit is a measure of the costs of debt. The Breusch-Pagan test on the OLS results detects heteroscedasticity; thus, the robust OLS estimator has been employed to estimate equation (3) on 15 regions.

\section{Data}

Variables employed in the estimates over the 2007-2014 period are described in Table 1 and are measured in euros, except for the dummy variable. The use of swap is investigated for all 15 Italian regions.

The yearly data have been collected from different sources: whereas data from the Italian National Bureau of Statistics (ISTAT), the Bank of Italy, and the Italian regional accounting system (Commission for Fiscal Federalism Development, or COPAFF) are fully accessible, the Corte dei Conti does not provide researchers access to its data. Therefore, the authors of this study manually compiled the first database of swaps, collecting data on notional values and total debt of regions from the tables published in the annual reports of the Corte dei Conti.

\section{[TABLE 1 ABOUT HERE]}

The second column of Table 1 reports the predictions between the dependent variable of equation (2), the region's total debt, and the explanatory variables.

Following Brailsford, Heaney, and Oliver (2005) and considering that the relationship between the two variables is simultaneous, a positive coefficient is expected between GDP local and Total debt because large regions are not likely to decrease their debt, especially in the period under consideration, characterised by a significant reduction of resources from the central state. 
The Interest expense includes payments related to all liabilities such as swaps. During the 2007-2014 period, a positive relationship is expected between Interest expense and Total debt because a higher debt burden leads to higher interest expenses. Tax revenues finance the region's expenditures and positively correlate with outstanding debt because regions with high outstanding debt are likely to further increase their taxes in periods of reduced transfers from the central state. According to the law, local authorities can issue loans with the Treasury at a fixed rate and later swap these liabilities. Because OTC derivatives are hedging contracts, their greater Notional value is the result of high outstanding debt. Table 2 shows the variables' descriptive statistics; the sample is an unbalanced panel dataset of 15 Italian regions with 135 region-year observations. The average total debt is $€ 2.84$ billion, of which $37 \%$ is healthcare and $63 \%$ is non-healthcare debt. Regardless of the economic downturn, in the period under observation, regions increased local taxes to fund services to citizens, with the average tax revenue at $€ 6.7$ billion. The average yearly interest expense is $€ 118$ million. The average Italian region's GDP is $€ 348$ billion. In $66 \%$ of the Italian regions, a left-wing political party is in charge, such as the Democratic Party. The average notional value of regions is €924 million, with high variability, as some regions did not use derivatives' contracts. Such a large variation confirms regions' different debt management strategies.

\section{[TABLE 2 ABOUT HERE]}

Table 3 shows the correlation amongst the analysed variables. Total debt exhibits a high correlation with the interest expense and notional value, a correlation lower than 0.5 with tax revenue, and a very low correlation with the GDP of the area and the political party dummy. Tax revenue has a correlation with GDP per capita greater than 0.5 , but its correlation with other variables is slightly lower than 0.5 . The notional value of swaps has a high correlation with total debt (0.7) and interest expense (0.6), whereas this figure is lower than 0.5 with the other variables. The political party dummy negatively correlates with all variables, except the GDP of the area. This can be explained by the fact that leftwing parties, such as the Democratic Party and Communist Party, have the political majority in smaller and less indebted regions (Liguria, Emilia Romagna, Tuscany, Umbria, Marche and Apulia), which represents a departure with respect to the history of the Italian stockpiling of debt. 


\section{[TABLE 3 ABOUT HERE]}

The debt repayment capacity of the local administration is influenced by the use of instruments such as swap contracts, and, to the best of our knowledge, no previous study has adequately investigated this rather important phenomenon.

Because a regulation on the use of derivatives was absent for most of the period under observation, over-indebted regions likely employed swaps in attempts to counterbalance the reduced resources received from the central state, in line with other countries' experience and not only to hedge their interest risks. Our empirical analysis investigates whether swaps have been used to finance discretionary debt during the 2007-2014 period. Table 4 describes the variables employed and reports the predictions between the dependent (Notional value) and independent (Interest expense and Non-healthcare debt) variables with regard to equation (3). We expect a positive relationship between the notional value and the non-healthcare debt and between the notional value and the interest expense; thus, being over-indebted should positively correlate with the notional value of swaps.

\section{[TABLE 4 ABOUT HERE]}

\section{Results}

This section discusses the results of the analysis of swaps' use by Italian regions.

Table 5 displays the empirical results by considering the variables' predictions reported in Table 1, to answer the first research question: What effects do swaps produce on Italian regions' debt? We first estimate equation (2) in Table 5A without considering the notional value of swaps to better compare the results with the literature, and later introduce the notional value in Table 5B.

In the absence of swaps (Table 5A), the empirical relationship between a region's total debt and its GDP is negative for the 15 regions analysed, confirming the relationship found by Figari and Gandullia (2008), according to whom the debt grew when GDP slowed down. However, this relationship may also have been accentuated by the economic crisis that persisted during most of the period under observation (2007-2014). The presence of left-wing ruling parties reduces the debt stockpiling, which represents a departure from the historical Italian experience. In the period under observation, rightwing parties manage highly indebted (and large) regions mostly located in the North of 
the country, and the reduction of debt by left-wing parties can be explained by the geographical distribution in the sample under analysis. The cost of debt (i.e. interest expense) and the total debt show a positive and significant coefficient with a stronger magnitude than tax revenues. The relationship between the tax revenues - the most important source of income for regions - and debt suggests that the sustainability of regions' debt is not high.

\section{[TABLE 5A ABOUT HERE]}

Larger regions (e.g. Piedmont, Lombardy, Lazio, and Campania) faced increasing demand for public services, but instead of increasing taxes, they preferred to smooth their cash flows and entered swap contracts. Indeed, our results confirm that a positive relationship between interest expenses and total debt exists. These results are consistent with the previous literature according to which local variables (i.e. GDP and political majorities) and financial variables (i.e. interests' expense and tax revenues) are determinants of debt of local administrations (Bahl and Duncombe, 1993; Kriz and Wang, 2012; Rodríguez Bolívar, Navarro Galera, Alcaide Muñoz, and López Subirés, 2016).

The pursue of cost-effectiveness and efficiency for Italian local administrations indirectly drove the use of swaps. Moreover, the absence of debt management principles accentuated the contractual opportunism and the principal-agent problem between the central state and the local administrations (Lane, 2005), reducing the so-called 'vertical' transparency of debt management (Mabillard and Zumofen, 2016).

We shall keep in mind that the empirical results are limited by the quality of information on swaps provided by regions and central authorities.

We consider the use of swaps, following equation (2) and results are reported in Table 5B. According to the Corte dei Conti (2016 and previous years), swaps had hedging purposes to manage the interest expenses, but our results show that they contributed to increasing the total debt.

According to the empirical evidence, regions with higher debt use more derivative contracts (measured with the notional value) to manage their interest exposure. The principal (the central state) did not limit the use of swaps by the agents (regions) during the period under observation. These results confirm that Italian regions implemented derivatives-based strategies, similar to the Italian Treasury (Lagna 2016) and French municipalities (Pérignon and Vallée, 2017). 


\section{[TABLE 5B ABOUT HERE]}

Table 6 shows the empirical results of the relationship between derivatives' notional value, non-healthcare debt and interest expenses for the 15 regions. The coefficient of the non-healthcare debt is positive and statistically significant, confirming that swaps have been used to finance discretionary (non-healthcare) debt. This evidence indicates the reverse causality of the agency problem. The coefficient of interest expenses is positive but not statically significant; this confirms the statement of the Corte dei Conti (2016 and previous years) according to which regions did not use swaps to pay interests expenses, differently from the French experience (Pérignon and Vallée, 2017). Based on these empirical results, we can affirm that swaps, measured with their notional value, significantly impacted the discretionary debt of regions.

\section{[TABLE 6 ABOUT HERE]}

Our findings are fully consistent with those reported in the public debt management literature (Brailsford, Heaney and Oliver; 2005; Khumawala, Ranasinghe, and Yan, 2016; Luby and Kravchuk, 2013) according to which swaps have significant effects on the debt of public administrations, and are new to the literature that never addressed the Italian case. The estimates from equations (2) and (3) fit the Italian data for regions, but the lack of detailed data inhibits further investigation and the use of more sophisticated econometric procedures, such as those implemented by Pérignon and Vallée (2017) and Khumawala et al. (2016).

\section{Conclusions and Implications}

Financial health is one of the goals of NPM and is a necessary condition under which governments at the central and local levels must operate. European governments are being pressured by citizens and other stakeholders to improve their efficiency and effectiveness while facing reductions in available resources. One indication that suggests that NPM has harmed Italian municipal governments is the widespread use of swaps hoping to raise extra funds and not only to hedge the interest rate risk, with a concomitant increase in exposure to financial risk. 
Other European countries have already suffered relevant losses due to the vicious debtswap cycle (i.e., France and Greece). Similarly to the French experience, this study confirms that Italian regions used swaps to finance part of their debt, but contrary to the Greece case, Italian regions did not use swaps to hide their debt.

A transparent (accrual-based) accounting system is the first step toward an effective debt management system; the second step would be the comprehensive assessment of the potential exposure, risks and costs of swap contracts relative to the level of debt. This requires the provision of detailed financial information of such contracts, in particular the counterpart(s), the duration, the fees, the scenario used to price the swap (including the hedge parameters), the default event description, the implicit (interest or exchange) rates and the existence of any conflict of interests with financial intermediaries.

This study fills a gap in the literature with the first empirical investigation in the aftermath of the financial crisis on the use of swaps by Italian ordinary statute regions over the period 2007-2014. Concerning the first research question, this study reveals that regions with higher levels of debt, like Campania, Piedmont, Lombardy, and Lazio, exhibit a higher interest rate exposure and employ more derivative contracts (notional value). This result is of certain relevance for citizens, given the poor quality of the information provided by authorities on such contracts.

The results imply that highly indebted regions (i.e. those that are with debt larger than $€ 2$ billion: Piedmont, Lombardy, Veneto, Tuscany, Lazio, Campania, and Apulia) with reduced funds from the central state and diminished resources were more likely to use swap to fund their debt. Indeed, Italian regions heavily depended on long-term debt to finance their non-healthcare services, rather than current revenues, such as taxes, leading to a significant increase in the financial leverage ratio. A higher leverage ratio is associated with greater financial risks, inducing regions to hedge their interest exposures with swaps. The fact that regions used swaps to financing discretionary debt indirectly confirms that transparency has not improved. Italian citizens know very little about derivatives' contract use and associated risks because of the lack of transparency in the regions' income statements and the complexity of the monitoring and supervision process: agents' actions are unobservable by the principal. This opaqueness limits the political losses associated with swaps' losses. Our empirical results confirm that severe agency problems emerge when the cost of current decisions can be shifted in the future or are not properly disclosed. 
Because highly indebted regions are more likely to further increase debt during a period of crisis such as 2007-2014, results imply that the use of swaps should be monitored and even limited by the central state. The Corte dei Conti asked for a parliamentary intervention, and the 2014 Budget Law (Italian Government, 2013) banned the use of swaps and other derivative products for all administrations, both central and local. However, this limit will be ineffective if the accounting and supervisory systems on liabilities are not developed; rules circumvention and regulatory arbitrage can severely reduce the effectiveness of the legislative ban. Local administrations should be equipped with an accounting and supervisory system to better manage financial risks. This administrative infrastructure can be quite expensive for small regions (i.e. Umbria, Marche, Molise, and Liguria).

As in other European countries facing severe downturns, the fragility of the Italian legislative system, the lack of responsibility of civil servants and public managers, the absence of an organic legislative framework concerning the use of OTC contracts, fragmented control, weakened monitoring and inadequate accounting procedures all contribute to scepticism regarding the use of swaps and strongly limit their financial benefits. 


\section{References}

Bahl, R. Duncombe, W. (1993), 'State and Local Debt Burdens in the 1980s: A Study in Contrast', Public Administration Review, Vol. 53 No. 1, pp. 31-40.

Bank of Italy (2016, 2018), Debito delle amministrazioni locali. Bank of Italy: Rome.

Bartram, S.M (2019), 'Corporate hedging and speculation with derivatives', Journal of Corporate Finance, Vol. 57, pp. 9-34.

Bodnar, G.M., Consolandi, C., Gabbi, G. and Jaiswal-Dale, A. (2013), 'Risk Management for Italian Non-Financial Firms: Currency and Interest Rate Exposure', European Financial Management, Vol. 19, pp. 887-910.

Brailsford, T., Heaney, R. and Oliver, B. (2005), 'Use of derivatives in public sector organizations', Accounting and Finance, Vol. 45, pp. 43-66.

Brusca I., and Montesinos, V. (2010), 'Developments in financial information by local entities in Europe', Journal of Public Budgeting, Accounting \& Financial Management, Vol. 22(3), 229-324, DOI: 10.1108/jpbafm-22-03-2010-b001

Carini, C., Giacomini, D., and Teodori, C. (2018), 'Accounting Reform in Italy and Perceptions on the Local Government Consolidated Report', International Journal of Public Administration, Vol. 42 No. 3, pp. 195-204.

Cohen, S., Bisogno, M., and Malkogianni, I. (2019), 'Earnings management in local governments: the role of political factors', Journal of Public Budgeting, Accounting \& Financial Management, Vol. 20 No. 3, p. 331-348.

Corte dei Conti (2001-16), Relazione sulla gestione finanziaria delle Regioni, Rome.

Cour des Comptes (2018), Rapport Publique Annuelle 2018, Fevriere, Paris.

Del Bo, C., and Sirtori, E. (2016), 'Additionality and regional public finance - Evidence from Italy', Environment and Planning C: Government and Policy, Vol. 34, pp. 855-878. Denison, D. V., and Gibson, J.B. (2013), 'Adjustable Rate Debt Overwhelms Jefferson County, AL Sewer Authority: A Tale of Market Risk, False Hope, and Corruption', Journal of Public Budgeting, Accounting \& Financial Management, Vol. 25 No. 1, pp. $311-356$.

Figari, F., and Gandullia, L. (2008), 'Il debito delle regioni a statuto ordinario: un'analisi delle determinanti', Rivista di diritto finanziario e scienza delle finanze, Vol. 2, pp. 200226.

Howell-Moroney, M. E. and Hall, J. L. (2011), 'Waste in the Sewer: The Collapse of Accountability and Transparency in Public Finance in Jefferson County, Alabama', 
Public Administration Review, Vol. 71 No. 2, pp. 232-42, DOI 10.1111/j.15406210.2011 .02334 .

Italian Government (2013), Budget Law of 2014. Law No. 14727 December, Rome.

Khumawala, S., T. Ranasinghe and Yan, C.Y. (2016), 'Why hedge? Extent, nature and determinants of derivative usage in U.S. municipalities', Journal of Accounting and $\begin{array}{llllll}\text { Public } & \text { Policy, } & \text { Vol. } & 35, & \text { pp. } & \text { 303-325, }\end{array}$ http://dx.doi.org/10.1016/j.jaccpubpol.2015.12.004.

Kriz, K., and Wang, Q. (2012), 'Debt Capacity, Management and Policy: Measuring and monitoring debt capacity and affordability' in Handbook of Local Government Fiscal Health: Debt Capacity, Management and Policy, Jones and Bartlett Publishers.

Lagna, A. (2016), 'Derivatives and the financialisation of the Italian state', New Political Economy, Vol. 21 No. 2, pp. 167-186.

Lane, J. (2005), Public Administration and Public Management: The Principal-agent Perspective, Routledge, London.

Luby, M. J. (2012), 'The Use of Financial Derivatives in State and Local Government Bond Refinancing: Playing with Fire or Prudent Debt Management?', Journal of Public Budgeting, Accounting and Financial Management, Vol. 24 No.1, pp. 1-31.

Luby, M. J., and Kravchuck, R. S. (2013), 'An Historical Analysis of the Use of Debt Related Derivatives by State Governments in the Context of the Great Recession', Journal of Public Budgeting, Accounting and Financial Management, Vol. 25 No. 2 pp. 276-310.

Luby, M. J., and Singla, A. (2014), 'A Descriptive Analysis of State Government DebtRelated Derivatives' Policies', Public Budgeting and Finance, Summer, pp. 105-125. Mabillard, V., and Zumofen, I. (2016), 'The complex relationship between transparency and accountability: A synthesis and contribution to existing frameworks', Public Policy and Administration, DOI: 10.1177/0952076716653651

Oldani, C. (2019), 'On the perils of structured loans financing in France and Italy',Global Policy, Vol. 10 No. 3, pp. 391-396.

Pérignon, C., and Vallée, B. (2017), 'The political economy of financial innovation: evidence from local governments', Review of Financial Studies, Vol. 30 No. 6, pp. 1903 1934, DOI:10.1093/rfs/hhx029

Piga, G. (2001), 'Do Governments Use Financial Derivatives Appropriately? Evidence from Sovereign Borrowers in Developed Economies', International Finance, Vol. 4 No. 2, pp. 189-219. 
Piperno, S. (2013), La finanza decentrata in Italia, Il Mulino, Bologna.

Rodríguez Bolívar, M. P., Navarro Galera, A., Alcaide Muñoz L., and López Subirés, M.D. (2016), 'Risk Factors and Drivers of Financial Sustainability in Local Government: An Empirical Study', Local Government Studies, Vol. 42 No. 1, pp. 29-51, DOI: 10.1080/03003930.2015.1061506.

Soverchia, M. (2010), 'Analyzing Governmental Accounting and Financial Reporting: Italy, European Union, and the United States', International Journal of Public Administration, Vol. 33, pp. 529-533, DOI: 10.1080/01900692.2010.507113.

Stewart, L. J., and Cox, C. A. (2008), 'Financial Reporting Standards', Journal of Public Budgeting, Accounting and Financial Management, Vol. 20 No. 4, pp. 466-83. 
Table 1 - Variables description and prediction using eq.2 - 15 Italian regions (2007-2014)

\begin{tabular}{|c|c|c|c|}
\hline Variable & Prediction & Description & Source \\
\hline Total Debt & Dep. Variable & Is the total debt in euro & Corte dei Conti \\
\hline $\begin{array}{l}\text { Swap Notional } \\
\text { Value }\end{array}$ & + & $\begin{array}{l}\text { Is the notional value of swaps at the } \\
\text { reporting date in euro }\end{array}$ & Corte dei Conti \\
\hline Tax Revenue & + & Revenue from proper taxes in euro & $\begin{array}{l}\text { Commissione tecnica paritetica per } \\
\text { l'attuazione del federalismo fiscale } \\
\text { COPAFF }\end{array}$ \\
\hline Interest Expense & + & Is the cost of debt in euro & $\begin{array}{l}\text { Commissione tecnica paritetica per } \\
\text { l'attuazione del federalismo fiscale } \\
\text { COPAFF }\end{array}$ \\
\hline $\begin{array}{l}\text { GDP of the area, } \\
\text { GDP per capita }\end{array}$ & - & Measure the size of the region in euro & Italian Bureau of Statistics ISTAT \\
\hline Political Party & + & $\begin{array}{l}\text { Dummy = } 1 \text { when a left wing party } \\
\text { rules (Democratic Party, Communist } \\
\text { other leftist parties) and }=0 \text { when a } \\
\text { right-wing party rules the Region } \\
\text { (Berlusconi-Forza Italia, Christian } \\
\text { Democratic party and Lega Nord). }\end{array}$ & Regions' Websites \\
\hline
\end{tabular}

Table 2 - Descriptive statistics - 15 Italian regions (2007-2014)

\begin{tabular}{lccccc}
\hline \multicolumn{1}{c}{ Variable } & Obs. & Mean & Std. Dev. & Min & Max \\
\hline Total Debt & 135 & $2,840,000,000$ & $3,520,000,000$ & $222,000,000$ & $19,900,000,000$ \\
$\quad$ of which: non-healthcare debt & 135 & $1,740,000,000$ & $1,960,000,000$ & $106,000,000$ & $8,660,000,000$ \\
Swap Notional Value & 135 & $924,000,000$ & $1,190,000,000$ & 0 & $5,210,000,000$ \\
Tax Revenue & 105 & $6,690,000,000$ & $5,150,000,000$ & $377,000,000$ & $23,700,000,000$ \\
Interest Expense & 135 & $118,000,000$ & $140,000,000$ & $9,882,108$ & $738,000,000$ \\
GDP Geogr. Area & 120 & $348,000,000,000$ & $99,100,000,000$ & $248,000,000,000$ & $535,000,000,000$ \\
GDP Per Capita & 105 & 24,665 & 5,657 & 16,101 & 35,127 \\
Political Party (dummy) & 135 & 0.66 & 0.48 & 0 & 1 \\
\hline
\end{tabular}

Table 3 - Variables' correlation - 15 Italian regions (2007-2014)

\begin{tabular}{|c|c|c|c|c|c|c|c|}
\hline & $\begin{array}{l}\text { Total } \\
\text { Debt }\end{array}$ & $\begin{array}{l}\text { Tax } \\
\text { Revenue }\end{array}$ & $\begin{array}{l}\text { GDP } \\
\text { Per } \\
\text { Capita }\end{array}$ & $\begin{array}{l}\text { GDP } \\
\text { Geogr. } \\
\text { Area }\end{array}$ & $\begin{array}{l}\text { Interest } \\
\text { Expense }\end{array}$ & $\begin{array}{c}\text { Political } \\
\text { Party }\end{array}$ & $\begin{array}{c}\text { Swap } \\
\text { Notional } \\
\text { Value }\end{array}$ \\
\hline Total Debt & 1.00 & & & & & & \\
\hline Tax Revenue & 0.43 & 1.00 & & & & & \\
\hline GDP Per Capita & 0.21 & 0.64 & 1.00 & & & & \\
\hline GDP Geogr. Area & 0.18 & 0.52 & 0.76 & 1.00 & & & \\
\hline Interest Expense & 0.94 & 0.44 & 0.27 & 0.18 & 1.00 & & \\
\hline Political Party (dummy) & -0.35 & -0.32 & -0.04 & 0.01 & -0.23 & 1.00 & \\
\hline Swap Notional Value & 0.69 & 0.25 & -0.19 & -0.04 & 0.60 & -0.29 & 1.00 \\
\hline
\end{tabular}


Table 4 - Variables description and prediction using eq.3 - 15 Italian regions (2007-2014)

\begin{tabular}{llll}
\multicolumn{1}{c}{ Variable } & Prediction & \multicolumn{1}{c}{ Description } & Source \\
\hline $\begin{array}{l}\text { Swap Notional } \\
\text { Value }\end{array}$ & Dep. Variable & Is the notional value of swaps in euro & Corte dei Conti \\
Interest expense & + & Is the cost of debt in euro & $\begin{array}{c}\text { Commissione tecnica paritetica } \\
\text { per l'attuazione del federalismo } \\
\text { fiscale - COPAFF }\end{array}$ \\
Non-healthcare debt & + & $\begin{array}{l}\text { Is the region's debt not due to } \\
\text { healthcare expenses measured in } \\
\text { euro }\end{array}$ & $\begin{array}{l}\text { Commissione tecnica paritetica } \\
\text { per l'attuazione del federalismo } \\
\text { fiscale - COPAFF }\end{array}$ \\
\hline
\end{tabular}

Table 5A - Robust OLS Estimates Results - Eq. 2 (2007-2014)

\begin{tabular}{lcc}
\hline Dep. Var. Total Debt & 15 Italian Regions \\
\hline GDP of the area & p-value & $-25,894.408$ \\
Political party & p-value & $-762,417,100^{* *}$ \\
& & $(0.01)$ \\
Interest expense & p-value & $21.53 * * *$ \\
& & $(0.00)$ \\
Tax revenue & p-value & 0.01 \\
& & $(0.68)$ \\
Constant & p-value & $1,398,269,000$ \\
& & $(0.09)$ \\
\hline R-squared (within) & & 0.88 \\
Number of obs. & & 75 \\
Fixed Effect & & Yes \\
\hline
\end{tabular}

Legenda: *,**,*** reports significance at $10 \%, 5 \%$ and $1 \%$ respectively 
Table 5B - Robust OLS Estimates Results - Eq. 2 (2007-2014)

\begin{tabular}{lcc}
\hline \multicolumn{2}{c}{ Dep. Var. Total Debt } & 15 Italian Regions \\
\hline GDP Geogr. Area & p-value & $32,029.391$ \\
Political Party & p-value & $(0.18)$ \\
Interest Expense & & $-601,435,400^{* *}$ \\
& p-value & $(0.00)$ \\
Tax Revenue & & $19.11^{* * *}$ \\
& p-value & $(0.00)$ \\
Swap Notional Value & & -0.02 \\
& p-value & $(0.37)$ \\
Constant & & $0.49 * *$ \\
& p-value & $(0.01)$ \\
R-squared (within) & & $-64,844,850$ \\
Number of obs. & & $(0.90)$ \\
Year Fixed Effect & & 0.90 \\
\hline
\end{tabular}

Legenda: *,**,*** reports significance at $10 \%, 5 \%$ and $1 \%$ respectively

Table 6 - Robust OLS Estimates Results - Eq. 3 (2007-2014)

\begin{tabular}{|c|c|}
\hline Dep. Var. Swap Notional Value & 15 Italian Regions \\
\hline Non-healthcare debt & $0.29 * * *$ \\
\hline 年 & $(0.00)$ \\
\hline \multirow{2}{*}{ Interest Expense } & 1.65 \\
\hline & $(0.12)$ \\
\hline \multirow[t]{2}{*}{ Constant } & $221,197,400$ \\
\hline & $(0.12)$ \\
\hline R-squared (within) & 0.41 \\
\hline Number of obs. & 135 \\
\hline Year Fixed Effect & Yes \\
\hline
\end{tabular}

Legenda: *,**,*** reports significance at $10 \%, 5 \%$ and $1 \%$ respectively 